\title{
THE YOGA OF INTERPERSONAL RELATIONSHIPS
}

\section{Dr Ananda Balayogi Bhavanani *}

\section{Introduction:}

All aspects of our human personality are cultured through the process of Yoga helping us evolve towards perfection until we are "One" with the Divine Self. Yoga helps destroy the Kleshas, the psychological afflictions that warp our vision, as well as eradicates Karma Bandha that prevents us from realizing our potential Divinity. Our great Rishis like Veda Vyasa and Maharishi Patanjali have given us a clear road map for this evolutionary journey with vital clues towards understanding both the internal and external culturing processes of Yoga. The cultural teachings of Yoga help us become "All One" by losing our sense of individuality to gain an unparalleled sense of universality.

In our day-to-day personal and inter-personal social life, Yoga has given us multitudes of tools, concepts, attitudes and techniques through which we can attain inner contentment leading to happiness and spiritual realization while simultaneously creating harmony in all relationships. All psychosocial qualities essential for healthy inter-personal relationships are cultivated when we live a life of Yoga that is in tune with the eternal Dharma. These humane qualities include loving understanding, innate sensibility that sees other's perspectives, compassion, empathy, respect, gratitude, fidelity and responsibility. In fact the Srimad Bhagavad Gita delineates very similar qualities of a spiritually healthy person in Chapter XVI. These include: fearlessness (Abhayam), purity of inner being (Sattva Samshuddhih), steadfastness in the path of knowledge (Jnanayoga Vyavasthitih), charity (Danam), self control (Dama), spirit of sacrifice (Yajna), self analysis (Svadhyaya), disciplined life (Tapa), uprightness (Arjavam), non violence (Ahimsa), truthfulness (Satyam), freedom from anger (Akrodhah), spirit of renunciation (Tyagah), tranquility (Shanti), aversion to defamation (Apaishunam), compassion to all living creatures (Daya Bhutesv), non covetedness (Aloluptvam), gentleness (Maardavam), modesty (Hrir Acaapalam), vigor (Tejah), forgiveness (Kshama), fortitude (Dhritih), cleanliness of body and mind (Saucam), freedom from malice (Adroho), and absence of pride (Naa Timaanita). One who is blessed with these qualities is indeed a divine blessing to the social life of their immediate family, friends, relatives and their society itself.

\section{The Four Pronged Approach:}

Our ancient Indian culture, a vibrant living culture till even today, has a lot to offer in every sphere of life. The elevated spiritual, psychological and metaphysical concepts of our great Maharishis hold true even today and it is up to us to delve into them and reap benefits of psycho-physiological health, happiness as well as intra-personal and inter-personal social harmony. Our Rishis were visionary seers who codified innumerable concepts that produce physically, emotionally and mentally healthy individuals who are valuable for betterment of society.

Our ancients in their infinite wisdom realised that we need to deal with different people differently. Some people can be held close whereas with others an arm's length or often a six feet pole's length is required. Sensitive, sensible people may respond to a soft carrot approach while the arrogant who are usually dull and inert may only respond to a heavy and strong stick. The Rishis have codified a four pronged approach to deal with different types of human personalities at different times and in different ways. Saint Thiyagaraja in his composition "sarasa sama dana bheda danda chatura" describes Lord Rama as the perfect example of a human possessing these qualities of Kingship and kinship.

The first of these four methods is known as Sama and is the dealing with people using a sense of equanimity and treating them as equals in the search for truth. This can only be applied with the noble ones and will be misused by others as seen in

\footnotetext{
* Dr Ananda Balayogi Bhavanani, Deputy Director, CYTER, Mahatma Gandhi Medical College and Research Institute, Puducherry 607402, India and Chairman: International Centre for Yoga Education and Research, and Yoganjali Natyalayam Puducherry. www.rishiculture.org and www.icyer.com
} 
today's chaotic environment. The second method is Dana, which implies the affording of concessions towards those who are truly needy. This may be in the material, physical, mental or emotional form and is the giving of a bit of leeway that can help those who are in trouble to come up to par with others and then slowly develop into one who can be treated at the Sama level. Bheda is the third method and is a separation from troublesome elements in order to reduce the extent of the problem. When used in a proper and judicious manner this can help many situations to normalize and prevent them from going from "bad to worse". When things get really bad or worse, then Danda or minimal deterrent action through judicious punishment can be of use when we considering the holistic picture.

In modern times the "spare the rod" mentality is prevalent and we do seem to end up spoiling our children and youth by making them weaker in all aspects. We take away their ability to be responsible citizens by teaching then indirectly that "anything that happens is not your fault- you are the victim". I reiterate clearly that I am not a supporter of any form of corporal punishment, but I do realize the need for a determent in order for the betterment of the whole. One rotten apple is all that we need to spoil a barrel and the same can be said of the repeated offenders. Such situations need to be nipped in the bud and the Danda method has its uses too in such situations. Of course this requires a lot of Viveka on the part of the parent, teacher or person in authority and also needs safety precautions so that it is not misused by ignorant egotistical persons who want to be the "star of the show" at the cost of the others. The most basic qualities required for a good parent, teacher and leader in any field of endeavor are intelligence and empathy. Yet how many of our people have these qualities today?

\section{Evolutionary Quirks of the Human Brain:}

Ammaji, Kalaimamani Meenakshi Devi Bhavanani often talks about the five quirks of the human brain and quotes the Ken Keyes Jr who in his book "Your Road Map to Lifelong Happiness" argues that there is an essential "lack of communication" between the "old" (reptilian - mammalian) and the "new" (conscious, neo-cortex) parts of the human brain. As the "old brain" developed over 60 to 375 million years it is powerful and well-set in its ways. Its habitual responses to environmental survival challenges are strong and automatic - "kill or be killed". On the other hand, the "New Brain" of human consciousness is only 40 to 100 thousand years old and hence the new boy on the block. The lack of communication between the old and new brains produces the "Five Quirks" that are the major causes behind innumerable problems we face in all interpersonal relationships. These quirks are:

1. The Object Quirk - the animal brain sees objects only in a very vague, hazy, general sense and not in a specific sense. It views objects and classifies them as to how they may fulfill its needs or in what way they may threaten its safety. Thus, it confuses different people and things. It sees everything generally as friend or foe, provider of food or as a sexual possibility. It does not need to see any object with specific characteristics. For example, it does not choose a mate on personal charm or elevated character but simply as a means to gratify sex drive. Other objects and other creatures are important only as means to satisfy basic needs.

2. The Time Quirk - Keyes says the "Old Brain" has no time sense. It does not perceive past or future. It lives only in the present moment. It "eats or is eaten." There is no sense of tomorrow or yesterday. Everything is immediate, now, urgent. At that lower level of life, every experience is in the "Now" of survival.

3. The Unsafe Stranger Quirk - The "Old Brain" views all strangers with suspicion. The "unknown stranger" is a possible threat to survival or a competitor for resources. Any creature "different" from oneself and one's species is a potential threat.

4. The Unchanging Entity Quirk - To the "Old Brain" incapable of perceiving subtleties, everything remains the same - a tree is always a tree. It does not perceive the various changes, which all things pass through. It sees all things as "unchanging" as the perception of intricate subtleties of change is not necessary for survival. 
5. Adaptable Memory Quirk - The animal does not need memory. The only memory necessary is what enables it to survive. Hence, what it remembers can be "adjusted" to whatever best helps it to survive. There is no objective truth. The only "Truth" to the animal brain is "survival of the fittest."

The manner in which animals and reptiles perceive the world is a much dimmer, less precise, less clear,survival-oriented perception totally geared to survival. This is much less than that available to the conscious mind. The "Old Brain" is fuelled by emotional responses. The basic motivating emotion is fear. The other important drives-sex, survival instinct, herd mentality, dominance, power struggles, nurturing and being nurtured-are all tied to the organism's basic need to survive at all costs and fear of death or extinction.

For example, the "Object Quirk" manifests in human experience when a person in the past was abused by a red-haired woman and hence, in future, always has a dislike for red-haired women. The "Old Brain" cannot see the possibility that all red-haired women will not abuse it. Similarly the Time Quirk manifests itself in human behavior in this manner: when one experiences unhappiness, one feels one is "always unhappy." This may cause one to perceive another person as "always angry", even though the person may only be angry at that moment. Witness how many husband-wife or parent-child quarrels begin with the words... 'You always do this..."

The "Unsafe Stranger Quirk" is evidenced in the suspicion that people feel when a foreigner enters their circle, or someone of a different religion a different race, a different culture etc comes into their social circle. There is an instinctual fear, even though that person may be perfectly harmless. This is highly visible in today's society where everyone wants "their" country, state, language, religion etc to be the "best". Linguistic, religious and regional fanaticism springs forth from such "old" conditioned responses that are so deeply ingrained in the animal brain that people lose all 'sense' and do things that they would never do in even their wildest dreams.
The "Unchanging Entity Quirk" manifests when people cannot see that those around them are constantly changing, that they are not what they were yesterday. A thief may have reformed himself, but others may always perceive him as "a thief."The husband may have overcome his bad habit, but the wife cannot see him anew. This is carried further by the "Adjustable Memory Quirk" that occurs when people deliberately or unconsciously "re-arrange" their memories to support or justify their emotions or desires. For example, a couple who wish to divorce may "adjust their memories' to "remember" only the "bad times" or the "bad characteristics" of their partners. This is very common in most relationships and cannot be overcome without awareness and consciousness that springs from introspectional self analysis of Swadyaya.

Animals are prisoners of their genes. They are incarnated into a conditioned, stimulus-response programming and they have no choice, but to follow their instincts. Man, the new being, the first "Conscious Organism" has the power of choice. $\mathrm{He} /$ she may now act, and choose to respond in a dignified and adequate manner, rather than react in an uncontrolled and totally inappropriate manner. The human being has the power to think, to recall past situations and compare them to the present reality. Man has the power of reason which frees him from the instinctive responses to challenge which is the mode of behavior of the reptilian and mammalian kingdom. But the power of the unconscious emotions and instincts rising from the "Old Brain" in a kind of "evolutionary lag" sometimes overpowers the "Rational Brain" and causes "The New Being" to react in an irrational manner. Man as a social, conscious being has lifted himself from the jungle environment with its moment to moment dangers and constant life and death challenges. He no longer faces challenges to his very survival on a constant basis. His life is relatively secure on the physical level (barring wars and other unusual circumstance). Yet, his "Old Brain" is hard wired to react as though every threat (physical or psychological) is a life and death matter. Hence, even psychological challenges, or innocuous frictions trigger off "Old Brain" extreme responses, especially on the emotional level. 
We can witness in so many human relationships that the old, animal and reptilian autonomic responses and reactions cloud the "human" or conscious perception. The "Old Brain" reacts out of past conditioning. It is heavily "loaded" with emotions which are part of the mammalian complex, and hence, "unconscious." The animal-reptile (Pashu) is not "free" to choose as it is bound by the tight noose (Pasha) of its conditioned stimulusresponse mechanism. If it is threatened, it will flee or fight. These are the only options open to it. We must remember that on the other hand, the "New Brain" has the power to act after considering the reality of the present situation. We have the choice of using discernment, rationality and deliberation to choose consciously our actions and responses in any given circumstance. This power of choice is concomitant to the event of consciousness. The multiple million dolor question is however, "Are we ready and willing to be real human beings?"

\section{Importance of Adhikara Yoga:}

The Pancha Yamaand Pancha Niyamaare considered as Adhikara Yoga by DrTR Anantharaman as they give us the self resplendent authority and inner resolve for spiritual realizations. They provide a strong moral and ethical foundation for our personal and social life. They guide our attitudes with regard to the right and wrong in our life and in relation to our self, our family unit and the entire social system.

The higher,conscious power to reflect, to perceive the current situation freed of all past conditioning, and then to consciously choose an appropriate response is the essence of Yama-Niyama, the moral and ethical system of Rishiculture Ashtanga Yoga. Yama may be understood to be a conscious restraint of primitive instincts and impulses rising from the "Old Brain." Yama is thus the control of our unconsciousness tendencies, our Vasanas and the deeply ingrained habitual patterns of our Samskaras. Niyama may be on the other hand said to be a positive and conscious reinforcement of the higher consciousness, those Divine characteristics that propel one's evolution into more advanced states of being. Niyama is the cultivation of consciousness. Pujya Swamiji, Gitananda Giri called the Yama and Niyama as "No-Option Yoga" for they are the "sarvabhauma mahavratam" of Maharishi Patanjali. If we want to grow, to evolve out of our reptilian - mammalian past into the truly human, humane and divine nature, we must restrain the primordial instincts through Yama and consciously reinforce our Divine nature through the observances and practice of Niyama.

The Pancha Yamas are Ahimsa (Non-violence), Satya (truthfulness), Asteya (non-stealing), Brahmacharya (control of the creative impulse) and Aparigraha (non - covetedness). These are the "DO NOT'S" in a Yoga Sadhaka's life. Do not kill, do not be untruthful, do not steal, do not waste your god given creativity and do not covet that which does not belong to you. These guide us to say a big "NO" to our lower self and the lower impulses of violence etc. When we apply these to our life we can definitely have better personal and social relationships as social beings.

The Pancha Niyamas are Soucha (cleanliness), Santhosha (contentment), Tapa (discipline), Swadyaya (study of one's-self) and Ishwar Pranidhana (gratitude to the Divine). The Pancha Niyamas guide us with "DO'S" - do be clean, do be contented, do be disciplined, do self - study (introspection) and do be thankful to the divine for all of his blessings. They help us to say a big "YES" to our higher self and the higher impulses. Definitely a person with such qualities is a Godsend to humanity.

We must remember that even if we are unable to live the Yama-Niyama completely, the attempt by us to do so will bear fruit and make us a better person, of value to those around us and a valuable person within our family and society. These are values which need to be introduced to our children and youth, making them aware and conscious of these wonderful concepts of daily living. These are indeed qualities that are to be imbibed in a natural and Sahaja manner and not learnt under the threat of fear or compulsion. The parents and teachers can by example show their children the importance of these qualities and when the children see the good examples of their parents and teachers living there principles they will surely follow suit sooner than later. 


\section{Other Important Yogic Concepts:}

There are many important Yogic concepts that help guide us in shaping our personal lives as well as helping us to create harmonious interpersonal relationships that make up our daily social life. Some examples of these spiritually uplifting concepts that transform all aspects of our social life include:

- Vasudeiva Kudumbakam: The whole world is one family. This is an excellent concept which helps one to understand that division on the basis of class, creed, religion and geographical distribution are all 'man made' obstructions towards oneness. One can then look upon all as his own and can bond with everyone irrespective of any barrier. All the great Yogic saints such as Tirumoolar, Tiruvalluvar, Basava, Periyalvar and Tirunavukkarasar have reminded us again and again in so many lovely verses of the singular teachings that there is only "One Humanity and One God".

- Chaturvidha Purusharthas: The four legitimate goals of life tell us how we can set legitimate goals in this life and work towards attaining them in the right way, following our dharma to attain Artha (material prosperity), Kama (emotional prosperity) and finally the attainment to the real goal of our life, Moksha (spiritual prosperity). These four are termed as Aram, Porul, Inbam and Veedu respectively in Nannool, an ancient Dravidian text and the great life enhancing teachings in the Tirukkural of Tiruvalluvar deal directly with the first three and hints at the fourth.

- PanchaKlesha: Avidya (ignorance),Asmita (ego), Raaga (attraction), Dwesha (repulsion) and Abinivesha (urge to live at any cost) are the five Kleshas or mental afflictions with which we are born into this human life. Through Yoga we can understand how these control our life and see their effects on our behavior. These 'Kleshas' hinder our personal and social life and must be destroyed through the practice of Patanjali's Kriya Yoga which is Tapa, Swadyaya and Ishwar Pranidhana.

- Jiva Karunya: Empathic compassion towards all living beings is extolled in the teachings of Tirumoolar, Tiruvalluvar and Vallalar
Ramalinga Adigalar. Tirumoolar says that the most important aspects of right living are the devoted loving offering to the Divine while in daily life the feedings of other human beings and animals with loving compassion. He also stresses the need of speaking good and kind words to others as the means to spiritual upliftment. Tiruvalluvar asks us the poignant question, "Of what use is intelligence if one cannot empathize with the pain of others and help them"

- Chatur Bhavana: The four attitudes that Patanjali advises us to cultivate are given in the 33rd Sutra of the Samadhi Pada. These attitudes that help us to control our mental processes are: friendliness towards those who are happy (Maitri - Sukha); compassion towards those who are miserable (Karuna - Dukha); cheerfulness towards the virtuous (Mudhita - Punya); and indifference towards the wicked (Upekshanam - Apunya). These help us create a Yogic attitude of Sama Bhava or equal mindedness in all situations. They also help us to overcome the Kleshas, and provide us with answers on how to live a Yogic life. They make us humane and help us to live within the social structure in a healthy and happy manner.

- Pratipaksha Bhavanam: The concept of Pratipaksha Bhavanam is an amazing teaching and must be inculcated in our Sadhana of dayto-day living as we face it so many times each day. Even if we cannot replace negative thoughts with emotion-laden positive reinforcements, we must at least make an attempt to stop them in their troublesome track! I have personally found that a strong "STOP" statement works wonders in helping block out the negative thoughts that otherwise lead us into the quicksand-like cesspool of deeper and greater trouble. Tiruvalluvar advises us to repay negative actions done to us by others with positive selfless actions towards them.

- Karma Yoga: Selfless action and the performance of our duty without any motive are qualities extolled by the Bhagavad Gita which is one of the main Yogic texts. Performing one's duty for the sake of the duty itself and not with any other motive helps us to develop detachment (Vairagya) which is a quality vital for a good life. Karma Yoga includes important concepts of 
action-reaction and teaches us the importance of right action. This includes the concepts of selfless action (Nishkama Karma) as well as skill in action (Karmasu Koushalam). Selfless action and the performance of our duty without any motive are qualities extolled by the Bhagavad Gita which is one of the main yogic texts. Performing one's duty for the sake of the duty itself and not with any other motive helps us to develop detachment (Vairagya) which is a quality vital for a good life. Yoga is skill in action according to Yogeshwar Krishna in the Bhagavad Gita. 'To do our best and leave the rest' is how Pujya Swamiji Gitananda Giri Guru Maharaj used to describe the best way of life. Even if we don't practice the other aspects of Yoga, we can be 'living'Yoga, by performing all our duties skill fully and to the best of our ability. A great teacher can be a true Yogi by performing doing their duty to perfection and without care for the rewards of the action, even if they do not practice any Asanas or Pranayama.

- Samatvam: 'Yoga is equanimity' says the Bhagavad Gita. Development of a complete personality who is neither affected by praise nor blame through development of Vairagya (detachment) leads to the state of "Stitha Prajna" or "Sama Bhava". This is a state of mind which is equally predisposed to all that happens, be it good or bad. Such a human is a boon to society and a pleasure to live and work with.

- Bhakti Yoga: The self effacing, loving path of Bhakti enables us to realize the greatness of the Divine and understand our puniness as compared to the power of the Divine or nature. We realize that we are but 'puppets on a string' following his commands on the stage of the world and then perform our activities with the intention of them being an offering to the Divine and gratefully receive HIS blessings. "It is only with the blessings of the Divine, that we can even worship his holy feet (avanarulal avan thal vanangi)" says the Shiva Puranam, a Shaivite Dravidian classic.

\section{Shifting From Individuality To Universality:}

Yoga, which emphasizes the universal, is a perfect foil to those human activities, which glorify the personal. The ego which is fixated only on its own shallow self will soon run into the blank wall of depression and despair, overwhelmed by its own superficiality. That striving spirit which looks within at the universal aspect of its own nature and sees the oneness of the whole of creation will find an endless fountain of inspiration and joy. In short it may be safely said that the practice of Yoga as a unified whole helps the individual shift from an 'I"-centric approach to a "we"-centric approach. Tirumoolar stresses the importance of cutting the ego sense (Anava Mala) in countless verses of the 3000 versed classic Tirumandiram.

Yoga not only considers the importance of attaining a dynamic state physical health but also more importantly mental health. Qualities of a mentally healthy person (Stitha Prajna) are enumerated in the Bhagavad Gita as follows:

- Beyond passion, fear and anger (veeta raga bhaya krodhah- II.56)

- Devoid of possessiveness and egoism (nirmamo nirahamkarah- II.7)

- Firm in understanding and un bewildered (sthira buddhir asammudhah- V.20)

- Engaged in doing good to all creatures (sarva bhutahiteratah- V.25)

- Friendly and compassionate to all ( maitrah karuna eva ca- XII.13)

- Pure hearted and skilful without expectation (anapekshah sucir daksah- XII.16)

Maharishi Patanjali tells us that we can gain unexcelled happiness, mental comfort, joy and satisfaction by practicing and attaining a state of inner contentment (santoshat anuttamah sukha labhah- PYS II: 42). This link is quite apparent once we think about it, but not too many associate the need for contentment in their greed for anything and everything in this material world. The Srimad Bhagavad Gita says, "yogaha karmasu koushalam” meaning thereby that Yoga is skill in action (II.50). The real Yogi, immensely conscious and aware at the physical, mental and emotional levels gains great control through that consciousness over all aspects of life thus developing a real skill in living. Part of that skill springs from his cultivated detachment, his ability to work for "work's sake," 
and not for the sake of the reward. He realizes that his duty is to do his best but that the ultimate result is not in his hands. The Yogi performs the needed action not for the sake of the fruits of that action, but because it is good and necessary to do so. Such an attitude of mind produces consummate skill in whatever action the Yogi undertakes. Consummate concentration, consummate controls are all offshoots of good Yoga Sadhana. This belies the age-old belief that the competitive spirit produces the highest skill. To this the Yogic answer is: detachment from the fruits of the action produces the greatest efficiency, for one is then emotions connected with "goal-oriented", competitive thinking. The beauty of Yoga is that these abstract principles become concrete in the daily practice of the techniques available in the Yoga system. Once the "Seed of Yoga" finds fertile soil, these concepts grow naturally, slowly but surely taking root in all aspects of life.

\section{Regaining Our Health And Happiness Through Yoga:}

"Health and happiness are your birthrights, Moksha is your goal. Reclaim your birthrights and attain your goal though Yoga" roared the Lion of Modern Yoga, Yogamaharishi Dr Swami Gitananda Giri. Living a happy and healthy life on all planes is possible through the unified practice of Hatha Yoga Asanas and Pranayamas, Dharana, Dhyana and Bhakti Yoga especially when performed consciously and with awareness. Asanas help to develop strength, flexibility, will power, good health, and stability and thus when practiced as a whole give a person a "stable and unified strong personality". Pranayama helps us to control our emotions which are linked to breathing and the Pranamaya Kosha (the vital energy sheath or body). Slow, deep and rhythmic breathing helps to control stress and overcome emotional hangups. Dharana and Dhyana help us to focus our mid and dwell in it and thus help us to channel our creative energy in a wholistic manner towards the right type of evolutionary activities. They help us to understand our self better and in the process become better humans in this social world.

The true Yogic life involves a sustained struggle against past conditioning, an attempt to control one's inner environment in order to focus inward. Yoga is isometric, pitting one part of the body against the other and the Yogi strives to be "more perfect today, than he/she was yesterday". It is practically impossible for classical Yoga Sports, Pranayamas and other Yoga practices to harm the practitioner when they are performed in the proper manner.

Yoga is not just performing some contortionist poses or huffing and puffing some Pranayama or sleeping our way through any so-called meditation. It is an integrated way of life in which awareness and consciousness play a great part in guiding our spiritual evolution through life in the social system itself and not in some remote cave in the mountains or hut in the forest. Yoga can be rightly said to be the science and art of right-useness of body, emotions and mind.

Tiruvalluvar says, "The loving ones live for the sake of others while the unloving live only for themselves". Yogis have immense love and compassion for all beings and wish peace and happiness not only for themselves, but for all living beings. They are not "individualists" seeking salvation for themselves but on the contrary are "universalists" seeking to live life in the proper evolutionary manner to the best of their ability and with care and concern for their fellow human brethren and those beings living at all planes of existence. This is well exemplified by Yogic prayers such as, "Om, loka samasta sukhino bhavanthu sarve janaha sukhino bhavanthu Om shanti, shanti, shanti Om”.

May we all become true Yogis as extolled by Yogeshwar Sri Krishna when he says, "tasmad yogi bhavarjuna -become thou a Yogi, Oh Arjuna”. Hari Om Tat Sat- May that be the reality!

\section{Suggested Reading:}

1. A Primer of Yoga Theory. Dr. Ananda Balayogi Bhavanani. Dhivyananda Creations, Iyyanar Nagar, Pondicherry. 2008.

2. A Yogic Approach to Stress. Dr Ananda Balayogi Bhavanani.. Dhivyananda Creations, Iyyanar Nagar, Pondicherry. (2nd edition) 2008.

3. Ancient Yoga and Modern Science. Dr. TR 
Anantharaman. Mushiram Manoharlal Publishers Pvt Ltd, New Delhi. 1996

4. Ashtanga Yoga of Patanjali. Dr Swami Gitananda Giri. Edited by Meenakshi Devi Bhavanani. Satya Press, Pondicherry.1995

5. Culturing one's self though Yoga. Ananda Balayogi Bhavanani. Yoga Mimamsa 2011; 43 (1): 84-94.

6. Evolutionary quirks, yama - niyama \& the human brain. Meenakshi Devi Bhavanani. Yoga Vijnana 2009; 2 (3 \&4): 1-8.

7. Frankly speaking. Dr Swami Gitananda Giri.Edited by Meenakshi Devi Bhavanani. Satya Press, Pondicherry.1995

8. Srimad Bhagavad Gita. Swami Swarupananda. Advaita Ashrama, Kolkata. 2007

9. Thiruvalluvar on Yogic Concepts. Meena
Ramanathan, Aarogya Yogalayam, Venkateswara Nagar, Saram, Pondicherry-13.2007

10. Tirumandiram: A Tamil Scriptural Classic. Translated by Dr. B. Natarajan, Sri Ramakrishna Math, Chennai. 2006

11. Understanding the Yoga Darshan. An Exploration of the Yoga Sutras of Maharishi Patanjali by Ananda Balayogi Bhavanani. Dhivyananda Creations, Pondicherry. 2011

12. Yoga for Health and Healing. Dr Ananda Balayogi Bhavanani. Dhivyananda Creations, Iyyanar Nagar, Pondicherry. 2007

13. Yoga Therapy Notes. Dr Ananda Balayogi Bhavanani. Dhivyananda Creations, Iyyanar Nagar, Pondicherry. 2007

14. Yoga: Step by Step. Dr Swami Gitananda Giri. Satya Press, Pondicherry. 1975 